Canadian

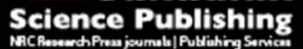

Botany

Botanique

\title{
Circinotrichum sinense, a new asexual fungus from Hubei, China
}

\begin{tabular}{|c|c|}
\hline Journal: & Botany \\
\hline Manuscript ID & cjb-2017-0132.R1 \\
\hline Manuscript Type: & Article \\
\hline Date Submitted by the Author: & 29-Sep-2017 \\
\hline Complete List of Authors: & $\begin{array}{l}\text { Li, De-Wei; The Connecticut Agricultural Experiment Station, Valley } \\
\text { Laboratory } \\
\text { Schultes, Neil; The Connecticut Agricultural Experiment Station, } \\
\text { Department of Plant Pathology and Ecology } \\
\text { Chen, Jing-Yuan; Hubei Academy of Forestry } \\
\text { Wang, Yi-Xun; Hubei Academy of Forestry } \\
\text { Castañeda-Ruiz, Rafael; Académico Titular de la Academia de Ciencias de } \\
\text { Cuba }\end{array}$ \\
\hline $\begin{array}{r}\text { Is the invited manuscript for } \\
\text { consideration in a Special } \\
\text { Issue? : }\end{array}$ & N/A \\
\hline Keyword: & Gyrothrix, Hyphomycetes, ITS, LSU, Asexual morph, Xylariales \\
\hline
\end{tabular}

\section{SCHOLARONE"}

Manuscripts 
1 Circinotrichum sinense, a new asexual fungus from Hubei, China

2 De-Wei Li ${ }^{1,2}$, Neil P. Schultes ${ }^{3}$, Jing-Yuan Chen ${ }^{4 *}$, Yi-Xun Wang ${ }^{4}$ and Rafael Felipe Castañeda-

3 Ruiz $^{5}$

4 (Initials to appear in final version as : Li, D.W., Schultes, N.P., Chen, J.Y., Wang, Y.X., and

5 Castañeda-Ruiz, R.F.)

$6{ }^{1}$ The Connecticut Agricultural Experiment Station, Valley Laboratory, 153 Cook Hill Road, Windsor, CT

7 06095, USA.e-mail: dewei.li@ct.gov

$8 \quad{ }^{2}$ Co-Innovation Center for Sustainable Forestry in Southern China, Nanjing Forestry University, Nanjing, $9 \quad$ Jiangsu 210037, China

10

$11{ }^{3}$ The Connecticut Agricultural Experiment Station, Department of Plant Pathology and Ecology, 123

12 Huntington Street, New Haven, CT 06511, USA. e-mail: neil.schultes@ct.gov

13

$14{ }^{4}$ Institute of Forest Protection, Hubei Academy of Forestry,

1539 Fenglin Road, Wuhan, Hubei 430075, China. e-mail: chenjinyuan@hbly.gov.cn;

16 jingyuanchen@hotmail.com.

17 e-mail: yixunwang@hotmail.com

18

$19{ }^{5}$ Instituto de Investigaciones Fundamentales en Agricultura Tropical 'Alejandro de Humboldt'(INIFAT),

20 Académico Titular de la Academia de Ciencias de Cuba, Calle 1 Esq. 2, Santiago de Las Vegas, C.

21 Habana, Cuba, C.P. 17200

22 e-mail: rfcastanedaruiz@gmail.com; rfcastaneda@inifat.co.cu

23

$24 *$ CORRESPONDENCE TO: chenjinyuan@hbly.gov.cn; jingyuanchen@hotmail.com 25 


\section{Abstract}

27 A setose hyphomycete was collected as part of a recent expedition for microfungi in the Duheyuan National Nature Reserve in Hubei, China. The conidia are typical of Circinotrichum,

29 being curved or falcate,-single-celled, colorless, smooth with a setula at the apical end, and similar to Circinotrichum rigidum. Circinotrichum sinense has a longer setula only at the apical

31 end and verrucose setae, while $C$. rigidum has a setula on both ends and smooth setae.

32 Phylogenetic analysis using ITS and LSU DNA sequence data and examination of morphological characters showed that this fungus cannot be identified as any previously described species of Circinotrichum. Thus, a new fungal taxon is described. A key to recognized species of Circinotrichum is also provided.

37 Key Words: Asexual morph, Gyrothrix, Hyphomycetes, ITS, LSU, Xylariales.

Introduction

Circinotrichum Nees was typified with C. maculiforme Nees (Nees von Esenbeck 1817).

41 Circinotrichum was later emended by Pirozynski (1962). It is a folicolous genus characterized by

42 unbranched, circinate or flexuous setae, and conidiophores reduced to conidiogenous cells,

43 which aggregate around the bases of setae (Pirozynski 1962); in contrast, the similar genus,

44 Gyrothrix (Corda) Corda develops repeatedly branched setae (Corda 1842; Pirozynski 1962;

45 Seifert et al. 2011). Twenty six epithets have been proposed in Circinotrichum (Index Fungorum 2017; MycoBank 2017). Seifert et al. (2011) accepted 13 species. Later, Circinotrichum cycadis

47 Crous \& R.G. Shivas was added to the genus (Crous et al. 2014). At present 14 taxa are accepted 48 and in addition to the type species, these taxa are C. britannicum P.M. Kirk, C. chathamiense 
49

50

51

52

53

54

55

McKenzie, C. cochinense V.G. Rao \& Varghese, C. cycadis Crous \& R.G. Shivas, C.

falcatisporum Piroz., C. flagelliforme Zucconi \& Onofri, C. flexuosum K.G. Karand. et al., C.

mediterraneum Rambelli, C. olivaceum (Speg.) Piroz., C. palmicola Joanne E. Taylor et al., C.

papakurae S. Hughes \& Piroz., C. poonense Piroz. \& S.D. Patil, C. rigidum B. Sutton. Twelve species are questionable or have been reassigned to other genera, including: Ceratocladium, Gyrothrix, Hortaea, Sarcopodium or Selenodriella (Index Fungorum 2017; Pirozynski 1962). No taxa of Circinotrichum have been linked to a sexual morph.

Crous et al. (2015a) showed that the genus Circinotrichum belongs to Xylariaceae, Xylariales and is paraphyletic based on the phylogenetic study using LSU data of Circinotrichum cycadis, C. maculiforme, and C. papakurae; thus, a current revision of this genus is warranted. Several phylogenetic studies on Xylariales have been published (Asgari and Zare 2011; Daranagama et al. 2014; Jaklitsch et al. 2016; Senanayake et al. 2015). Eleven families (Apiosporaceae, Cainiaceae, Coniocessiaceae, Diatrypaceae, Hyponectriaceae, Iodosphaeriaceae, Lopadostomaceae, Melogrammataceae, Pseudomassariaceae, Vialaeaceae and Xylariaceae) were accepted by Senanayake et al. (2015) using ITS and partial nucLSU sequences. Among this group two new families, Lopadostomaceae and Pseudomassariaceae were proposed.

Graphostromataceae is doubtful, since it is imbedded in Xylariaceae (Senanayake et al. 2015). Jaklitsch et al. (2016) excluded Iodosphaeriaceae and accepted 16 families in Xylariales including six additional families: Amphisphaeriaceae, Beltraniaceae, Microdochiaceae, Phlogicylindriaceae, Requienellaceae, and Sporocadaceae based on phylogenetic analysis of the same nuclear loci (ITS and LSU). The family Clypeosphaeriaceae (Amphisphaeriales) cannot be maintained since the generic type of Clypeosphaeria, C. mamillana, belongs to the Xylariaceae (Jaklitsch et al. 2016). However, multiple locus phylogenetic analyses using ITS, 
72 LSU and SSU showed that Xylariaceae could be polyphyletic (unpublished data). Recently,

73 another new family, Castanediellaceae, was proposed (Hernández-Restrepo et al. 2017) and

74 Hypoxylaceae had been resurrected (Wendt et al. 2017). The delineation of Xylariales remains

75 unsettled and further studies are necessary.

A specimen of Circinotrichum collected from Hubei, China was determined to be new to

77 science based on its morphological characters and phylogenetic analysis using ITS and LSU

78 sequences data. Thus, it is illustrated and described in this paper and its phylogenetic

79 relationships with allied taxa is discussed.

80

81 Materials \& Methods

82 A collecting trip was made to the Duheyuan National Nature Reserve, Guangdu, Zhushan county,

83 Hubei, China in September 2016 to collect saprobic microfungi on plant debris. The specimens

84 were first examined using a stereomicroscope (Olympus SZX7). Microfungi were mounted in 85\%

85 lactic acid for further observation. Conidia were picked up from the specimen-using an

86 inoculation needle, transferred to two plates of malt extract medium (MEA) (20 g malt, $20 \mathrm{~g}$ agar

87 and $1 \mathrm{~L}$ distilled water) and incubated at $25^{\circ} \mathrm{C}$ for two weeks. Since the colonies failed to

88 sporulate, hyphal tips were cut from a colony edge to obtain a pure isolate. Four more MEA

89 plates were prepared from the purified isolate and incubated at $25^{\circ} \mathrm{C}$ on MEA for two weeks to

90 observe the colony growth and for preparing extype and molecular work. Each plate was

91 inoculated at three points in a triangle shape with equal distance. To monitor sporulation, Corn

92 meal agar (CMA: $1 \mathrm{~L}$ water, $17 \mathrm{~g}$ corn meal agar ), Oat meal (OA), and Potato dextrose agar

93 (PDA: 1L water, 200g potatoes, $20 \mathrm{~g}$ dextrose, $20 \mathrm{~g}$ agar) media were also used with the isolate

94 for a two weeks growth period. 
All further microscopic observations and measurements of fungal structures were made

96

97

The type specimen has been deposited in The Connecticut Agricultural Experiment Station (NHES) in the USA, and an extype culture has been deposited in The UAMH Centre for Global Microfungal Biodiversity at University of Toronto (UAMH), Canada.

DNA extraction and sequencing.-DNA was extracted from the fungus grown in a Petri dish of MEA medium according to the procedure in ZR Fungal/Bacterial DNA MicroPrep Kit (Zymo Research, Irvine, California). A combination of primers ITS5 and LR1 were used to amplify a fragment corresponding to the partial small subunit rDNA and internal transcribed spacer 1 and 2 region (ITS) (Vilgalys and Hester 1990; White et al. 1990). The primers 5.8SR and LR7 were similarly used to amplify a portion of the large subunit rDNA region (LSU) (Vilgalys and Hester 1990; White et al. 1990). The primers SR1R and SR6 were used to amplify the small subunit rDNA region (SSU) (White et al., 1990). The parameters for the PCR amplification protocol were $94{ }^{\circ} \mathrm{C} 3$ minutes; $94{ }^{\circ} \mathrm{C} 30$ seconds; $45^{\circ} \mathrm{C} 30$ seconds; $72{ }^{\circ} \mathrm{C} 2$ minutes, repeat $35 \mathrm{X}, 72{ }^{\circ} \mathrm{C}$ 7 minutes. The resulting PCR products were purified using QIA quick PCR Purification columns (Qiagen, Valencia, California) and the DNA concentration determined on a NanoDrop Lite Spectrophotometer (ThermoScientific, Waltham, Massachusetts). The ITS PCR products were sequenced using primers ITS1, ITS2, ITS3 and LR1. The LSU PCR products were sequenced 
118

119

120

121

122

123

124

125

126

127

128

129

130

131

132

133

134

135

136

137

138

139

140

using primers LROR, LR7, LR5, LR3R, LR16 and LR3B (5' GGTTAAGTTCAGCGGGT 3').

The SSU PCR products were sequenced using primers SR1R, SR1, SR2, SR4, SR6 and SR7R.

All DNA sequencing was performed at the W. M. Keck Biotechnology Resource

Laboratory, Yale School of Medicine (New Haven, Connecticut). DNA sequences were

deposited to GenBank (ITS KY994106, LSU KY994107, SSU KY994108).

Sequence similarity searches and comparisons were conducted using MegaBLAST

(Morgulis et al. 2008; Wheeler et al. 2003) for ITS, LSU, and SSU against the NCBI nucleotide

database to choose DNA sequences from allied fungal taxa for phylogenetic analyses.

Circinotrichum, Gyrothrix and 10 additional allied genera (39 taxa/isolates) were chosen for

phylogenetic analysis (TABLE 1). Penicillium chrysogenum (CBS 306.48) was designated as an outgroup. Since a SSU sequence is available from only three of the allied taxa, SSU sequences are not included in the phylogenetic analysis.

Independently, ITS and LSU DNA sequences were aligned using MUSCLE (Edgar 2004), and the resulting aligned data trimmed and concatenated using FABOX sequence alignment joiner (http://users-birc.au.dk/biopv/php/fabox/alignment_joiner.php\#). Phylogenetic analyses were conducted using the neighbor joining and maximum likelihood procedures in MEGA7 (Kumar et al. 2016). A bootstrap test was carried out with 1000 replicates. Bayesian inference was analyzed using MrBAYES3.2.6 (Ronquist et al. 2012). Four Markov chains were executed using 4 runs from random starting trees for 20 million generations. Trees sampling frequency was 1000 generations. The first 10\% generations were discarded as burn-in. The majority rule consensus tree of all remaining trees was calculated. Branches that received bootstrap support $(\geq 80 \%)$ and Bayesian posterior probabilities (BPP) ( $\geq 95 \%$ (BPP), respectively, were set as significantly supported. Phylogenetic trees were drawn with TREEVIEW 1.6.6 (Page 1996). 


\section{Results}

Phylogenetic analysis using ITS and LSU showed that Circinotrichum sinense

UAMH11913 is sister to C. falcatisporum, in the same clade as C. maculiforme (generic type), and Gyrothrix circinata, and subtended by Lopadostoma and Anthostomella. Circinotrichum

146 cycadis and C. papakurae are in a different clade with G. inops, G. ramosa, and Idriella lunata 147 (MUCL4103) (FIG. 1).

\section{Taxonomy}

Circinotrichum sinense D.W. Li, Neil P. Schultes, Jing Y. Chen, Yi X. Wang \& R.F. Castañeda

152 sp. nov.

FIG. 2

153 MycoBank MB 821257

Typification: China, Hubei, Zhushan county, Guangdu, Bailihe village, Yingzuiyan, partial immersed and partially superficial, composed of pale brown, smooth, branched, 1.5-3 $\mu \mathrm{m}$

161 wide, septate hyphae. Setae acicular or subulate, rarely obtuse, erect, straight or flexuous, simple,

162 thick-walled, verrucose, septate, dark brown, occasionally with percurrent extension, 115-260

$163 \mu \mathrm{m}$ in length, 4-8 $\mu \mathrm{m}$ wide at the base, with most gradually tapering to an acutely pointed or 
164 obtuse apex. Conidiophores reduced to conidiogenous cells. Conidiogenous cells enteroblastic,

165 phialidic, sometimes with several successive inconspicuous annellations, after percurrent

166 extensions, frequently collapsed near the apex, integrated, ampulliform to lageniform, colorless

167 to pale brown, thin-walled, smooth, arising at right angles from the vegetative mycelium, solitary

168 or gregarious at the base of setae, $5-7(-9) \times(2.7-) 3-4(-4.5) \mu \mathrm{m}(\mathrm{mean} \pm \mathrm{SD}: 6 \pm 1 \times 3.5 \pm 0.5$

$169 \mu \mathrm{m}, \mathrm{n}=26)$. Conidia acrogenous in white masses, curved or falcate, 1-celled, colorless, smooth,

$170(12-) 14.5-17(-18.5) \times(1.6-) 2-2.5 \mu \mathrm{m}($ mean \pm SD: $16 \pm 1.5 \times 2 \pm 0.2 \mu \mathrm{m}, \mathrm{n}=30)$, obtuse at the

171 base and abruptly attenuate with a cellular appendage at the apex, $(0.5-) 1-1.5(-2) \mu \mathrm{m}$ long

$172(1.5 \pm 0.5 \mu \mathrm{m}, \mathrm{n}=30)$. Sexual morph: not observed.

173

Colonies on MEA, effuse, white; retaining $9 \mathrm{~mm}$ diam. in two weeks at $25^{\circ} \mathrm{C}$. Mycelium

174 mostly immersed, partially superficial. No sporulation on MEA, CMA, OA and PDA in two

175 weeks.

176 Comments: Although Circinotrichum sinense is morphologically similar to $C$.

177 chathamiense and C. rigidum it can be differentiated from C. chathamiense by its smaller, 178 setulate conidia and phialidic conidiogenous cells $(14.5-17 \times 2-2.5 \mu \mathrm{m})$ vs. C. chathamiense 179 (20-24 × 1.5-2 $\mu \mathrm{m}$ conidia without setula) (McKenzie 1993). Both Circinotrichum sinense and 180 C. rigidum develop "phialidic" conidiogenous cells and conidia with similar size and shape.

181 However, Circinotrichum sinense has a longer setula only at the apical end and verrucose setae, 182 while $C$. rigidum has a setula on both ends and smooth setae (Sutton 1980). The three specimens 183 -including holotype IMI223850 of C. rigidum studied by Sutton (1980) - are no longer available 184 at the Kew Botanic Garden. The two taxa cannot be examined for detailed morphological 185 comparison. Since cultures of the morphologically related species, C. chathamiense and $C$. 
186 rigidum, are not available, the phylogenetic relationships of Circinotrichum sinense with $C$.

187 chathamiense and C. rigidum remain undetermined.

188

189

\section{Discussion}

Our phylogenetic analysis confirmed the conclusion of Crouse et al. (2015a) and

191 Hernandez-Restrepo et al. (2017) that Circinotrichum belongs to Xylariales (FIG. 1) and the 192 clade of Circinotrichum sinense, C. maculiforme, C. falcatisporum, as well as Gyrothrix 193 circinata, a sister to the clade including Lopadostoma spp. and Anthostomella spp. (FIG. 1). 194 Circinotrichum, Gyrothrix, and Idriella, as currently defined, are polyphyletic. Circinotrichum 195 sinense is sister to C. falcatisporum in the same clade as C. maculiforne and G. circinata, and 196 subtended by Lopadostoma, including its generic type L. turgidum and Anthostomella. Crous et 197 al. (2015a) concluded that the genus Circinotrichum belongs to Xylariaceae, Xylariales based on 198 their phylogenetic study using LSU data of Circinotrichum cycadis, Circinotrichum maculiforme, 199 and Circinotrichum papakurae, while in their analysis, Lopadostoma gastrinum was in the same 200 clade of Xylariaceae, Xylariales. Our analysis is in agreement with the results of Hernández201 Restrepo et al. (2017) that the placement of Circinotrichum at the family level remains unsolved. 202 However, Lopadostomataceae was proposed and typified with Lopadostoma to accommodate 203 Lopadostoma spp. and Creosphaeria based on ITS and LSU data (Senanayake et al. 2015). 204 Microdochiaceae was established and typified with Microdochium phragmitis to accommodate 205 Idriella, Microdochium, and Selenodriella based on LSU sequence data (Hernandez-Restrepo et 206 al. 2016). Delineation of Lopadostomataceae and Microdochiaceae needs to be further studied 207 prior to determine the placement of Circinotrichum at family level. Our results showed that 
208 several clades remain uncertain and the phylogeny of Xylariales has not been fully elucidated.

209 Thus, further studies are necessary in the future.

211 are closely related. Based on their phylogenetic analysis using ITS, LSU and tef1 $\alpha$ sequence data,

212 Becerra-Hernández et al. (2016) showed that Gyrothrix as a polyphyletic genus of Xylariales.

213 However, no culture of the type species of Gyrothrix, G. podosperma (Corda) Rabenh.

214 (三Campsotrichum podospermum Corda) is available. Thus, the phylogenetic placement of the

215 genus Gyrothrix at the family level cannot be determined at present.

216 According to our phylogenetic analysis, Gyrothrix circinata is in the same clade with the

217 generic type species, Circinotrichum maculiforme (FIG. 1). Thus, Gyrothrix circinata belongs in

218 Circinotrichum. However, the result showed that the four isolates of G. circinata are not con-

219 specific, therefore, no new combination for G. circinata is proposed until a further study is

220 conducted to examine its type material and an epitype culture can be designated. Our results

221 suggest that one of the generic characters of Circinotrichum, unbranched setae, should be

222 amended and widened to 'unbranched or branched setae'.

223 Gyrothrix circinata and G. podosperma are morphologically similar in conidial shape and

224 size and subdichotomous branching, rough setae (Pirozynski 1962). The conidia of both taxa are

225 cylindrical to fusoid, straight or slightly curved and similar in size, $8-16 \times 1.2-2 \mu \mathrm{m}$ for $G$.

226 podosperma and 12-15 × 1.5-1.8 $\mu \mathrm{m}$ for G. circinata (Pirozynski 1962). The main difference is

227 setae branching and height. Gyrothrix podosperma has setae 120-260 $\mu \mathrm{m}$ long with twisted or

228 loose spiral branching, while G. circinata develops setae 80-140 $\mu \mathrm{m}$ long with circinate

229 branching (Pirozynski 1962). Gyrothrix podosperma and G. circinata share all generic characters

230 of Circinotrichum except for one, which is branched circinate or spiral setae (Pirozynski 1962). 
231 A further study is needed to determine the placement of Gyrothrix podosperma, the generic type

232 of Gyrothrix. The members of Circinotrichum that do not develop circinate setae should be

233 further studied. The phylogenetic relationships among Circinotrichum, Gyrothrix and Idriella

234 remain to be determined due to the unavailability of cultures of a number of key taxa.

Circinotrichum sinense, a saprobe on leaf litter of Camellia cuspidata, was collected from

236 Duheyuan National Nature Reserve, a transitional area between south temperate and north

237 subtropics (Gao et al. 2012). There is no sign or symptom to indicate that a fungal disease has

238 been caused by $C$. sinense on the leaves $C a$. cuspidata. Duheyuan National Nature Reserve is

239 very rich in biodiversity and its flora has an ancient origin. The Reserve contains at least 2440

240 species of vascular plants, belonging to 949 genera, 212 families (Gao et al. 2012) including 39

241 genera are endemic in China (Gao et al. 2012; Pu et al. 2005). Camellia cuspidata is native to

242 forests of south eastern China at (100-)500-1500(-2200) m (Zhang and Ren 1998). No study or

243 survey on microfungi and fungal diversity has been conducted in this area in the past. Clearly

244 more undescribed fungal taxa, especially endemic ones are expected to exist in the area. It is

245 imperative to conduct studies on microfungi, fungal diversity and functions in this ecological

246 sensitive area in the near future.

247

248 Key to recognized species of Circinotrichum

249

250 1. Setae circinate only or both circinate and straight/flexuous .....

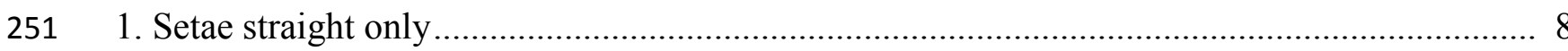

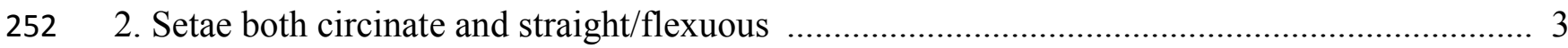

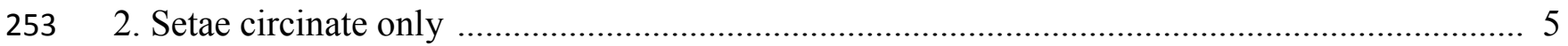


254 3. Setae both circinate and straight; conidia 8-12 $\mu \mathrm{m}$ long

C. poonense

255 3. Setae both circinate and flexuous

256 4. Setae 70-153 $\mu \mathrm{m}$ long, conidia 3.5-7 $\mu \mathrm{m}$ long

C. flexuosum

257 4. Setae 120-210 $\mu \mathrm{m}$ long, conidia 15-17 $\mu \mathrm{m}$ long

C. cochinense

$258 \quad 5$. Setae $25-75 \mu \mathrm{m}$ long

$259 \quad 5$. Setae $75-180 \mu \mathrm{m}$ long 7

260 6. Setae thin-walled, 25-40 $\mu \mathrm{m}$ in length; conidia 9-11 $\mu \mathrm{m}$ long

C. cycadis

261 6. Setae thick-walled, 35-75 $\mu \mathrm{m}$ in length; conidia 8.5-13 $\mu \mathrm{m}$ long.

C. olivaceum

262 7. Conidia straight or slightly curved, 9-17 $\mu \mathrm{m}$ long

C. maculiforme

263 7. Conidia falcate, $17.5-21 \mu \mathrm{m}$ long.

C. falcatisporum

264 8. Conidia setulose

265 8. Not setulose

9. Conidia with a setula at both ends, $13-16.5 \times 1.5 \mu \mathrm{m}$

C. rigidum

267 9. Conidia with a setula at the apical end, $14.5-17 \times 2-2.5 \mu \mathrm{m}$

C. sinense

268 10. Conidia cylindrical, straight.

269 10. Conidia curved or fusiform

270 11. Conidia $12-16 \mu \mathrm{m}$ long

C. britannicum

271 11. Conidia 12-20 $\mu \mathrm{m}$ long with mucilage drops at one or both ends, developing

272 two kinds of setae

C. palmicola

273 12. Setae up to $600 \mu \mathrm{m}$ in height, conidia $16-20 \times 2.3-2.7 \mu \mathrm{m}$.

C. flagelliforme

274 12. Setae $<600 \mu \mathrm{m}$ in height

13

275 13. Conidia $11-17 \times 1.5-2 \mu \mathrm{m}$

C. papakurae 
$276 \quad$ 13. Conidia $>20 \mu \mathrm{m}$ long

277 14. Conidia 20-24 × 1.5-2 $\mu \mathrm{m}$

C. chathamiense

278 14. Conidia 25-28 $\times 4 \mu \mathrm{m}$

C. mediterraneum

279

280

Acknowledgments

281 This work was partially supported by the USDA National Institute of Food and Agriculture,

282 Hatch project CONH00813. We are appreciative to Drs. John Soghigian, Robert Marra and

283 Blaire T. Steven for their technical assistance. The authors are appreciative to Dr. James A.

284 LaMondia of The Connecticut Agricultural Experiment Station (CAES) for his pre-submission

285 review. RFCR is grateful to Organización Superior de Dirección Empresarial Grupo Agrícola,

286 (OSDE) from Cuban Ministry of Agriculture.

287

288

\section{References}

289 Asgari, B., and Zare, R. 2011. A contribution to the taxonomy of the genus Coniocessia

290 (Xylariales). Mycological Progress, 10(2): 189-206. doi: 10.1007/s11557-010-0688-z.

291 Becerra-Hernández, C.I., González, D., De Luna, E., and Mena-Portales, J. 2016. First report of

292 pleoanamorphy in Gyrothrix verticiclada with an Idriella-like synanamorph. Cryptogamie,

293 Mycologie, 37(2): 241-252. doi: 10.7872/crym/v37.iss2.2016.241.

294 Corda, A.C.J. 1842. Anleitung zum Studium der Mykologie. Friedrich Ehrlich, Prague. pp. 1295223.

296 Crous, P.W., Schumacher, R.K., Wingfield, M.J., Lombard, L., Giraldo, A., Christensen, M.,

297 Gardiennet, A., Nakashima, C., Pereira, O.L., and Smith, A.J. 2015a. Fungal systematics and 
298 299

300 301

302

evolution: FUSE 1. Sydowia, 67: 81-118. doi: http://dx.doi.org/10.12905/0380.sydowia67-20150081

Crous, P.W., Shivas, R.G., Quaedvlieg, W., van der Bank, M., Zhang, Y., Summerell, B.A., Guarro, J., Wingfield, M.J., Wood, A.R., Alfenas, A.C., Braun, U., Cano-Lira, J.F., Garcia, D., Marin-Felix, Y., Alvarado, P., Andrade, J.P., Armengol, J., Assefa, A., den Breeyen, A., Camele, I., Cheewangkoon, R., De Souza, J.T., Duong, T.A., Esteve-Raventos, F., Fournier, J., Frisullo, S., Garcia-Jimenez, J., Gardiennet, A., Gene, J., Hernandez-Restrepo, M., Hirooka, Y., Hospenthal, D.R., King, A., Lechat, C., Lombard, L., Mang, S.M., Marbach, P.A., Marincowitz, S., Marin-Felix, Y., Montano-Mata, N.J., Moreno, G., Perez, C.A., Perez Sierra, A.M., Robertson, J.L., Roux, J., Rubio, E., Schumacher, R.K., Stchigel, A.M., Sutton, D.A., Tan, Y.P., Thompson, E.H., van der Linde, E., Walker, A.K., Walker, D.M., Wickes, B.L., Wong, P.T., and Groenewald, J.Z. 2014. Fungal Planet description sheets: 214-280. Persoonia, 32(1): 184-306. doi: https://doi.org/10.3767/003158514X682395.

Crous, P.W., Wingfield, M.J., Guarro, J., Hernandez-Restrepo, M., Sutton, D.A., Acharya, K., Barber, P.A., Boekhout, T., Dimitrov, R.A., Duenas, M., Dutta, A.K., Gene, J., Gouliamova, D.E., Groenewald, M., Lombard, L., Morozova, O.V., Sarkar, J., Smith, M.T., Stchigel, A.M., Wiederhold, N.P., Alexandrova, A.V., Antelmi, I., Armengol, J., Barnes, I., Cano-Lira, J.F., Castaneda Ruiz, R.F., Contu, M., Courtecuisse, P.R., da Silveira, A.L., Decock, C.A., de Goes, A., Edathodu, J., Ercole, E., Firmino, A.C., Fourie, A., Fournier, J., Furtado, E.L., Geering, A.D., Gershenzon, J., Giraldo, A., Gramaje, D., Hammerbacher, A., He, X.L., Haryadi, D., Khemmuk, W., Kovalenko, A.E., Krawczynski, R., Laich, F., Lechat, C., Lopes, U.P., Madrid, H., Malysheva, E.F., Marin-Felix, Y., Martin, M.P., Mostert, L., Nigro, F., Pereira, O.L., Picillo, B., Pinho, D.B., Popov, E.S., Rodas Pelaez, C.A., Rooney-Latham, S., Sandoval-Denis, M., Shivas, 
321 R.G., Silva, V., Stoilova-Disheva, M.M., Telleria, M.T., Ullah, C., Unsicker, S.B., van der

322 Merwe, N.A., Vizzini, A., Wagner, H.G., Wong, P.T., Wood, A.R., and Groenewald, J.Z. $2015 b$.

323 Fungal Planet description sheets: 320-370. Persoonia, 34: 167-266. doi:

$32410.3767 / 003158515 \times 688433$.

325 Cunningham, J.L. 1974. A new Gyrothrix in culture and a key to species. Mycologia, 66: 122326129.

327 Daranagama, D.A., Camporesi, E., Tian, Q., Liu, X., Chamyuang, S., Stadler, M., and Hyde, 328 K.D. 2015. Anthostomella is polyphyletic comprising several genera in Xylariaceae. Fungal 329 Divers. 73(1): 203-238. doi: 10.1007/s13225-015-0329-6.

330 Daranagama, D.A., Liu, X., Chamyuang, S., Stadler, M., and Hyde, K. 2014. A multiple gene 331 genealogy reveals phylogenetic placement of Rhopalostroma lekae. Phytotaxa, 186(4): 177-187. 332 doi: http://dx.doi.org/10.11646/phytotaxa.186.4.1.

333 Edgar, R.C. 2004. MUSCLE: multiple sequence alignment with high accuracy and high 334 throughput. Nucleic Acids Res. 32(5): 1792-1797. doi: 10.1093/nar/gkh340.

335 Gao, E.-H., Wang, Z.-X., and Wang, Z.-C. 2012. Scientific research on the Duheyuan Nature 336 reserve of Hubei Province [湖北堵河源自然保护区科学考察与研究]. Science Press, Beijing. 337 pp. 309.

338 Hernández-Restrepo, M., Gené, J., Castañeda-Ruiz, R., Mena-Portales, J., Crous, P., and Guarro, 339 J. 2017. Phylogeny of saprobic microfungi from Southern Europe. Studies in Mycology, 86: 53340 97. doi: 10.1016/j.simyco.2017.05.002. 
341 Hernandez-Restrepo, M., Groenewald, J.Z., and Crous, P.W. 2016. Taxonomic and phylogenetic

342 re-evaluation of Microdochium, Monographella and Idriella. Persoonia, 36: 57-82. doi:

$34310.3767 / 003158516 \times 688676$.

344 Houbraken, J., Frisvad, J.C., Seifert, K., Overy, D.P., Tuthill, D., Valdez, J., and Samson, R.

345 2012. New penicillin-producing Penicillium species and an overview of section Chrysogena.

346 Persoonia, 29(1): 78-100. doi: 10.3767/003158512X660571.

347 Index Fungorum. 2017. Index Fungorum. Available from http://www.indexfungorum.org

$348 \quad$ [accessed January 5 2017].

349 Jaklitsch, W., Fournier, J., Rogers, J., and Voglmayr, H. 2014. Phylogenetic and taxonomic

350 revision of Lopadostoma. Persoonia, 32(1): 52-82. doi: DOI: 10.3767/003158514X679272.

351 Jaklitsch, W., Gardiennet, A., and Voglmayr, H. 2016. Resolution of morphology-based

352 taxonomic delusions: Acrocordiella, Basiseptospora, Blogiascospora, Clypeosphaeria,

353 Hymenopleella, Lepteutypa, Pseudapiospora, Requienella, Seiridium and Strickeria. Persoonia-

354 Molecular Phylogeny and Evolution of Fungi, 37: 82-105. doi:

355 http://dx.doi.org/10.3767/003158516X690475.

356 Kumar, S., Stecher, G., and Tamura, K. 2016. MEGA7: Molecular Evolutionary Genetics

357 Analysis version 7.0 for bigger datasets. Mol. Biol. Evol. 33(7): 1870-1874. doi:

$358 \quad 10.1093 / \mathrm{molbev} / \mathrm{msw} 054$.

359 Lombard, L., Van der Merwe, N., Groenewald, J., and Crous, P. 2015. Generic concepts in

360 Nectriaceae. Studies in Mycology, 80: 189-245. doi: 10.1016/j.simyco.2014.12.002. 
361 Marincowitz, S., Crous, P.W., Groenewald, J.Z., and Wingfield, M.J. 2008. Microfungi occuring 362 on'Proteaceae'in the Fynbos. CBS Fungal Biodiversity Centre.

363 McKenzie, E. 1993. New hyphomycete species from litter in the Chatham Islands, New Zealand. 364 Mycotaxon, 46: 291-297.

365 Morgulis, A., Coulouris, G., Raytselis, Y., Madden, T.L., Agarwala, R., and Schäffer, A.A. 2008.

366 Database indexing for production MegaBLAST searches. Bioinformatics, 24(16): 1757-1764.

367 doi: 10.1093/bioinformatics/btn322.

368 MycoBank. 2017. MycoBank (Fungal Databases Nomenclature and Species Banks). Available 369 from www.mycobank.org [accessed March 8 2017].

370 Nees von Esenbeck, C. 1817. Das System der Pilze und Schwämme. Stahelsche Buchhandlung, 371 Würzburg.

372 Page, R.D. 1996. TreeView: an application to display phylogenetic trees on personal computers. 373 Computer Applications in the Biosciences, 12(4): 357-358.

374 Peršoh, D., Melcher, M., Graf, K., Fournier, J., Stadler, M., and Rambold, G. 2009. Molecular 375 and morphological evidence for the delimitation of Xylaria hypoxylon. Mycologia, 101(2): 256376 268. doi: $10.2307 / 20619173$.

377 Pirozynski, K.A. 1962. Circinotrichum and Gyrothrix. Mycological Papers, 84: 1-28.

378 Platas, G., Ruibal, C., and Collado, J. 2004. Size and sequence heterogeneity in the ITS1 of 379 Xylaria hypoxylon isolates. Mycol. Res. 108(01): 71-75. 
380 Pu, Y., Zhang, Y., Jiang, M., Shi, D., Cao, G., and Zheng, D. 2005. Study on plant diversity of 381 Duheyuan Nature Reserve on the northern slope of Mt. Shennongjia, Hubei, China. Wuhan 382 Botanical Research, 24(4): 327-332.

383 Ronquist, F., Teslenko, M., van der Mark, P., Ayres, D.L., Darling, A., Höhna, S., Larget, B., 384 Liu, L., Suchard, M.A., and Huelsenbeck, J.P. 2012. MrBayes 3.2: efficient Bayesian 385 phylogenetic inference and model choice across a large model space. Syst. Biol. 61(3): 539-542. 386 doi: 10.1093/sysbio/sys029.

387 Ropars, J., Cruaud, C., Lacoste, S., and Dupont, J. 2012. A taxonomic and ecological overview 388 of cheese fungi. Int. J. Food Microbiol. 155(3): 199-210. doi: 10.1016/j.ijfoodmicro.2012.02.005.

389 Seifert, K.A., Morgan-Jones, G., Gams, W., and Kendrick, B. 2011. The Genera of 390 Hyphomycetes. CBS-KNAW Fungal Biodiversity Centre Utrecht, Utrecht, The Netherlands. pp. 391997.

392 Senanayake, I.C., Maharachchikumbura, S.S.N., Hyde, K.D., Bhat, J.D., Jones, E.B.G., 393 McKenzie, E.H.C., Dai, D.Q., Daranagama, D.A., Dayarathne, M.C., Goonasekara, I.D., Konta, 394 S., Li, W.J., Shang, Q.J., Stadler, M., Wijayawardene, N.N., Xiao, Y.P., Norphanphoun, C., Li, 395 Q., Liu, X.Z., Bahkali, A.H., Kang, J.C., Wang, Y., Wen, T.C., Wendt, L., Xu, J.C., and 396 Camporesi, E. 2015. Towards unraveling relationships in Xylariomycetidae (Sordariomycetes). 397 Fungal Divers. 73(1): 73-144. doi: 10.1007/s13225-015-0340-y.

398 Summerbell, R.C., Gueidan, C., Schroers, H.J., de Hoog, G.S., Starink, M., Rosete, Y.A., Guarro, 399 J., and Scott, J.A. 2011. Acremonium phylogenetic overview and revision of Gliomastix, 
400 Sarocladium, and Trichothecium. Studies in Mycology, 68: 139-162. doi:

$401 \quad 10.3114 / \operatorname{sim} .2011 .68 .06$.

402 Sutton, B. 1980. Microfungi from Australian leaf litter. Proceedings of the Royal Society of 403 Queensland, 91: 11-19.

404 Vilgalys, R., and Hester, M. 1990. Rapid genetic identification and mapping of enzymatically 405 amplified ribosomal DNA from several Cryptococcus species. J. Bacteriol. 172(8): 4238-4246. 406 doi: $10.1128 / \mathrm{jb} .172 .8 .4238-4246.1990$

407 Wendt, L., Sir, E.B., Kuhnert, E., Heitkämper, S., Lambert, C., Hladki, A.I., Romero, A.I., 408 Luangsa-ard, J.J., Srikitikulchai, P., Peršoh, D., and Stadler, M. 2017. Resurrection and 409 emendation of the Hypoxylaceae, recognised from a multigene phylogeny of the Xylariales. 410 Mycological Progress, doi: 10.1007/s11557-017-1311-3.

411 Wheeler, D.L., Church, D.M., Federhen, S., Lash, A.E., Madden, T.L., Pontius, J.U., Schuler, 412 G.D., Schriml, L.M., Sequeira, E., Tatusova, T.A., and Wagner, L. 2003. Database resources of 413 the National Center for Biotechnology. Nucleic Acids Res. 31(1): 28-33. doi:

414 https://doi.org/10.1093/nar/gkg033.

415 White, T.J., Bruns, T., Lee, S., and Taylor, J. 1990. Amplification and direct sequencing of 416 fungal ribosomal RNA genes for phylogenetics. In PCR protocols: a guide to methods and 417 applications. Edited by M.A. Innis and D.H. Gelfand and J.J. Sninsky and T.J. White. Academic 418 Press, Inc., New York. pp. 315-322.

419 Zhang, H.-D., and Ren, S.-X. 1998. Flora of China. Science Press, Beijing, China. 


\section{Legends}

422 Fig. 1. Maximum Likelihood analysis of Circinotrichum sinense and allied taxa based on

423 concatenated ITS, and LSU sequence data. Penicillium chrysogenum is included as outgroup.

424 The bootstrap test was conducted with 1000 replicates. Bootstrap values $>80 \%$ (before the slash)

425 and Bayesian posterior probabilities ( $>95 \%$ ) (behind the slash) were indicated at the nodes. The

426 scale bar indicates the number of expected changes per site. T indicated the ex-types used in the

427 analysis.

428

429 Fig. 2. Circinotrichum sinense (NHES L1703) A. Seta and conidiogenous cell (arrow), B. Apical

430 portion of seta showing percurrent extension (arrow), C-D. Basal portion of seta and

431 conidiogenous cells (arrows). Scale bars: $\mathrm{A}=10 \mu \mathrm{m}, \mathrm{B}-\mathrm{E}=5 \mu \mathrm{m}$.

432

433 Table 1. Taxa and their sequences used in the phylogenetic analysis. 


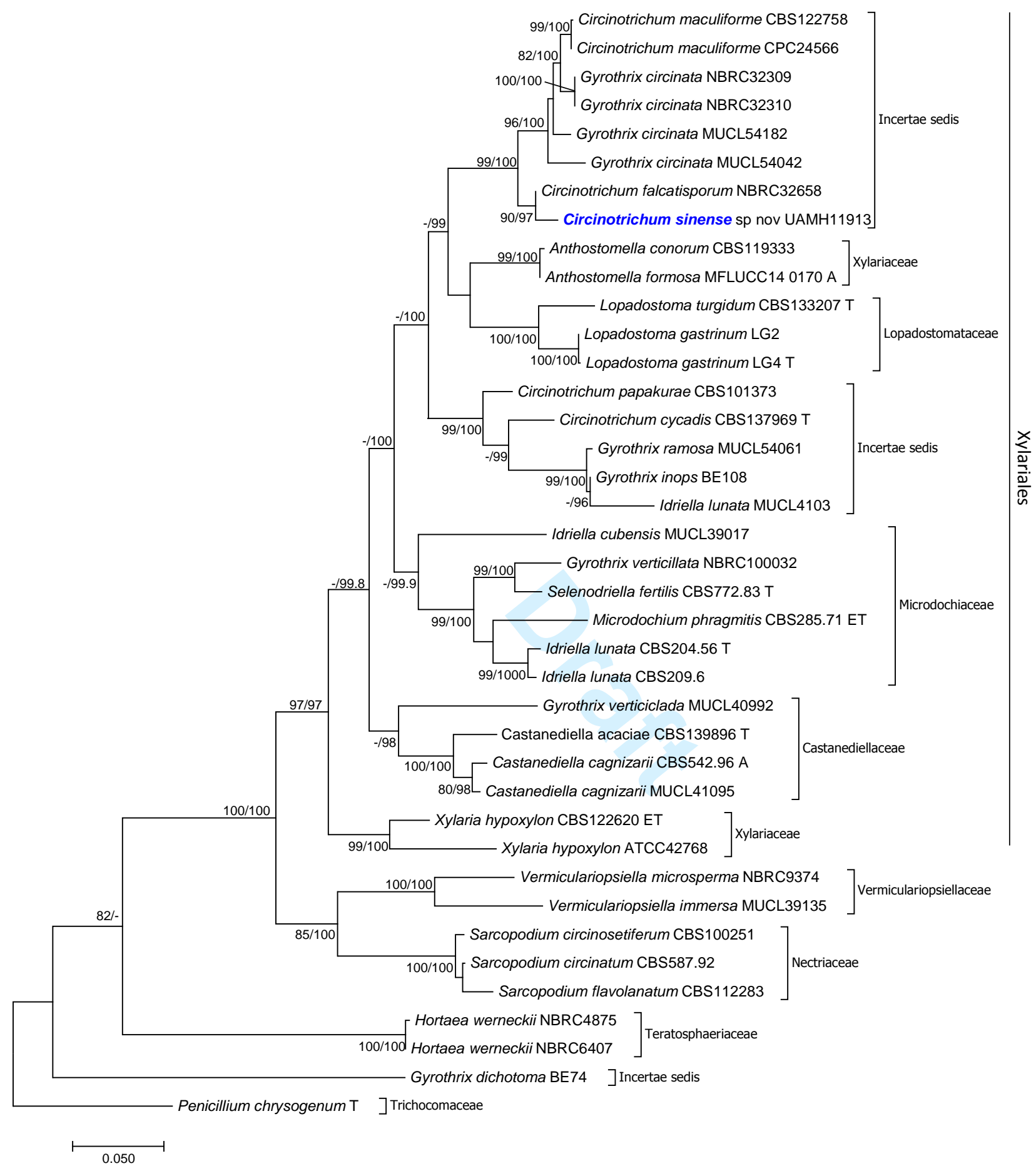




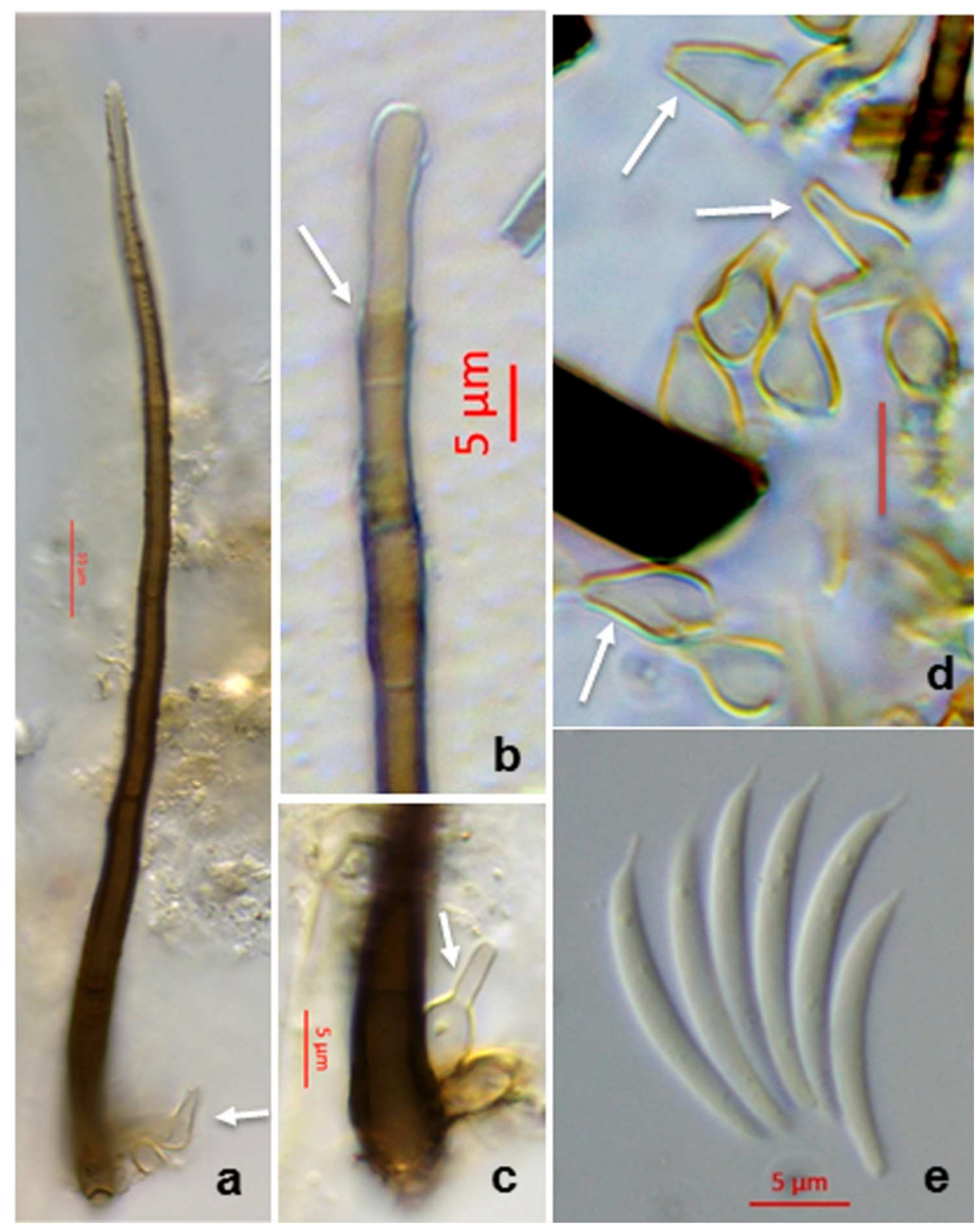

Fig. 2. Circinotrichum sinense (NHES L1703) A. Seta and conidiogenous cell (arrow), B. Apical portion of seta showing percurrent extension (arrow), C-D. Basal portion of seta and conidiogenous cells (arrows). Scale bars: $A=10 \mu \mathrm{m}, \mathrm{B}-\mathrm{E}=5 \mu \mathrm{m}$.

$223 \times 279 \mathrm{~mm}(300 \times 300$ DPI) 
1 Table 1. Circinotrichum sinense and allied taxa and their sequences used in the phylogenetic analysis.

\begin{tabular}{|c|c|c|c|c|c|c|c|c|c|}
\hline \multirow[t]{2}{*}{ Taxa } & \multirow[t]{2}{*}{ Strain Accession \# } & \multirow[t]{2}{*}{ Locality } & \multirow[t]{2}{*}{ Substrate } & \multicolumn{2}{|c|}{ Sequence accession \# } & \multirow[t]{2}{*}{ References } & \multirow{2}{*}{$\begin{array}{l}\text { Type } \\
\text { (T)/Epit } \\
\text { ype } \\
\text { (ET) } \\
\text { (A) } \\
\text { authenti } \\
\text { c }\end{array}$} & \multirow[t]{2}{*}{ Family } & \multirow[t]{2}{*}{ Order } \\
\hline & & & & ITS & LSU & & & & \\
\hline $\begin{array}{l}\text { Anthostomella } \\
\text { conorum }\end{array}$ & CBS 119333 & South Africa & $\begin{array}{l}\text { Protea neriifolia } \\
\text { dead leaves }\end{array}$ & EU552099 & EU552099 & $\begin{array}{l}\text { (Marincowitz } \\
\text { et al. 2008) }\end{array}$ & & Xylariaceae & Xylariales \\
\hline $\begin{array}{l}\text { Anthostomella } \\
\text { formosa }\end{array}$ & MFLUCC 14-0170 & Italy & $\begin{array}{l}\text { on needle of Pinus } \\
\text { sylvestris }\end{array}$ & - & KP340544 & $\begin{array}{l}\text { (Daranagama } \\
\text { et al. 2015) }\end{array}$ & A & Xylariaceae & Xylariales \\
\hline Castanediella acaciae & CBS 139896 & Malaysia & $\begin{array}{l}\text { leaf spots of Acacia } \\
\text { mangium }\end{array}$ & NR_137985 & KR47676 & $\begin{array}{l}\text { (Crous et al. } \\
2015 b \text { ) }\end{array}$ & $\mathrm{T}$ & $\begin{array}{l}\text { Castanediellacea } \\
\mathrm{e}\end{array}$ & Xylariales \\
\hline $\begin{array}{l}\text { Castanediella } \\
\text { (Idriella) cagnizarii }\end{array}$ & CBS 542.96 & Cuba & leaf litter & KP859054 & KP858991 & $\begin{array}{l}\text { (Hernandez- } \\
\text { Restrepo et } \\
\text { al. 2016) }\end{array}$ & A & $\begin{array}{l}\text { Castanediellacea } \\
\text { e }\end{array}$ & Xylariales \\
\hline $\begin{array}{l}\text { Castanediella } \\
\text { (Idriella) cagnizarii }\end{array}$ & MUCL41095 & Brazil & - & KC775732 & KC775707 & $\begin{array}{l}\text { (Becerra- } \\
\text { Hernández et } \\
\text { al. 2016) }\end{array}$ & & $\begin{array}{l}\text { Castanediellacea } \\
\text { e }\end{array}$ & Xylariales \\
\hline $\begin{array}{l}\text { Circinotrichum } \\
\text { cycadis }\end{array}$ & CBS 137969 & Australia & Leaves of Cycas sp. & KJ869121 & KJ869178 & $\begin{array}{l}\text { (Crous et al. } \\
2014 \text { ) }\end{array}$ & $\mathrm{T}$ & Incertae sedis & Xylariales \\
\hline $\begin{array}{l}\text { Circinotrichum } \\
\text { falcatisporum }\end{array}$ & NBRC 32658 & Japan & $\begin{array}{l}\text { dead leaf sheath, } \\
\text { Satakentia } \\
\text { liukiuensis }\end{array}$ & - & 3265801 & - & & Incertae sedis & Xylariales \\
\hline $\begin{array}{l}\text { Circinotrichum } \\
\text { maculiforme }\end{array}$ & $\begin{array}{l}\text { CBS } 122758=\text { FMR } \\
9645\end{array}$ & Spain & Plant debris & KR611875 & KR611896 & $\begin{array}{l}\text { (Crous et al. } \\
\text { 2015a) }\end{array}$ & & Incertae sedis & Xylariales \\
\hline $\begin{array}{l}\text { Circinotrichum } \\
\text { maculiforme }\end{array}$ & $\begin{array}{l}\text { CPC 24566=CBS } \\
140016\end{array}$ & Czech Republic & $\begin{array}{l}\text { Twig of Loranthus } \\
\text { europaeus }\end{array}$ & KR611874 & KR611895 & $\begin{array}{l}\text { (Crous et al. } \\
\text { 2015a) }\end{array}$ & & Incertae sedis & Xylariales \\
\hline $\begin{array}{l}\text { Circinotrichum } \\
\text { papakurae }\end{array}$ & $\begin{array}{l}\text { CBS } 101373= \\
\text { INIFAT C98/17-8 }\end{array}$ & Brazil & Rotten leaf & KR611876 & KR611897 & $\begin{array}{l}\text { (Crous et al. } \\
\text { 2015a) }\end{array}$ & & Incertae sedis & Xylariales \\
\hline $\begin{array}{l}\text { Circinotrichum } \\
\text { sinense }\end{array}$ & UAMH 11913 & China & $\begin{array}{l}\text { dead foliage of } \\
\text { Camellia cuspidata }\end{array}$ & KY994106 & KY994107 & This study & $\mathrm{T}$ & Incertae sedis & Xylariales \\
\hline Gyrothrix circinata & MUCL 54182 & Australia & - & KC775744 & KC775719 & $\begin{array}{l}\text { (Becerra- } \\
\text { Hernández et } \\
\text { al. 2016) }\end{array}$ & & Incertae sedis & Xylariales \\
\hline Gyrothrix circinata & NBRC 32309 & Japan & $\begin{array}{l}\text { dead leaf of } \\
\text { Trachycarpus } \\
\text { excelsa }\end{array}$ & NBRC 32309 & NBRC 32309 & - & & Incertae sedis & Xylariales \\
\hline Gyrothrix circinata & NBRC 32310 & Japan & $\begin{array}{l}\text { dead leaf of } \\
\text { Trachycarpus }\end{array}$ & NBRC 32310 & NBRC 32310 & - & & Incertae sedis & Xylariales \\
\hline
\end{tabular}




\begin{tabular}{|c|c|c|c|c|c|c|c|c|c|}
\hline & & & excelsa & & & & & & \\
\hline Gyrothrix circinata & MUCL54042 & Mexico & Leaf litter & KJ476967 & KJ476963 & \multicolumn{2}{|l|}{$\begin{array}{l}\text { (Becerra- } \\
\text { Hernández et } \\
\text { al. 2016) }\end{array}$} & Incertae sedis & Xylariales \\
\hline Gyrothrix dichotoma & BE108 & México & - & KC775745 & KC775720 & \multicolumn{2}{|l|}{$\begin{array}{l}\text { (Becerra- } \\
\text { Hernández et } \\
\text { al., 2016) }\end{array}$} & Incertae sedis & Xylariales \\
\hline Gyrothrix inops & BE74 & Cuba & - & KC775746 & KC775721 & \multicolumn{2}{|l|}{$\begin{array}{l}\text { (Becerra- } \\
\text { Hernández et } \\
\text { al., 2016) }\end{array}$} & Incertae sedis & Xylariales \\
\hline Gyrothrix ramosa & MUCL54061 & Cuba & - & KC775747 & KC775722 & \multicolumn{2}{|l|}{$\begin{array}{l}\text { (Becerra- } \\
\text { Hernández et } \\
\text { al., 2016) }\end{array}$} & Incertae sedis & Xylariales \\
\hline Gyrothrix verticiclada & MUCL40992 & Venezuela & - & KC775748 & $\begin{array}{l}\text { KC775rcinotr } \\
\text { ichum } \\
723\end{array}$ & \multicolumn{2}{|l|}{$\begin{array}{l}\text { (Becerra- } \\
\text { Hernández et } \\
\text { al., 2016) }\end{array}$} & $\begin{array}{l}\text { Castanediellacea } \\
\mathrm{e}\end{array}$ & Xylariales \\
\hline Gyrothrix verticilata & NBRC 100032 & Spain & $\begin{array}{l}\text { Submerged leaf } \\
\text { from a stream }\end{array}$ & 10003201 & 10003201 & \multicolumn{2}{|l|}{$\begin{array}{l}\text { (Becerra- } \\
\text { Hernández et } \\
\text { al., 2016) }\end{array}$} & Microdochiaceae & Xylariales \\
\hline $\begin{array}{l}\text { Hortaea } \\
\text { (Circinotrichum) } \\
\text { werneckii }\end{array}$ & $\begin{array}{l}\text { ATCC } 11717=\text { CBS } \\
410.51=\text { NBRC } 4875\end{array}$ & Japan & Air & 487501 & 487501 & \multicolumn{2}{|l|}{-} & $\begin{array}{l}\text { Teratosphaeriace } \\
\text { ae }\end{array}$ & Capnodiales \\
\hline Hortaea werneckii & NBRC6407 & - & - & & 640701 & \multicolumn{2}{|l|}{ - } & $\begin{array}{l}\text { Teratosphaeriace } \\
\text { ae }\end{array}$ & Capnodiales \\
\hline Idriella cubensis & MUCL39017 & Cuba & - & KC775733 & KC775708 & \multicolumn{2}{|l|}{$\begin{array}{l}\text { (Becerra- } \\
\text { Hernández et } \\
\text { al., 2016) }\end{array}$} & Microdochiaceae & Xylariales \\
\hline Idriella lunata & CBS 204.56 & USA & $\begin{array}{l}\text { Root of Fragaria } \\
\text { chiloensis var. } \\
\text { ananassa }\end{array}$ & KP859044 & KP858981 & $\begin{array}{l}\text { (Hernandez- } \\
\text { Restrepo et } \\
\text { al. 2016) }\end{array}$ & $\mathrm{T}$ & Microdochiaceae & Xylariales \\
\hline Idriella lunata & CBS 209.60 & The Netherlands & & KP859045 & KP858982 & \multicolumn{2}{|l|}{$\begin{array}{l}\text { (Hernandez- } \\
\text { Restrepo et } \\
\text { al. 2016) }\end{array}$} & Microdochiaceae & Xylariales \\
\hline Idriella lunata & MUCL4103 & Canada & - & KC775734 & KC775709 & \multicolumn{2}{|l|}{$\begin{array}{l}\text { (Becerra- } \\
\text { Hernández et } \\
\text { al., 2016) }\end{array}$} & Incertae sedis & Xylariales \\
\hline $\begin{array}{l}\text { Lopadostoma } \\
\text { gastrinum }\end{array}$ & CBS $133210=$ LG2 & - & Ulmus glabra & KC774581 & KC774581 & \multicolumn{2}{|l|}{$\begin{array}{l}\text { (Jaklitsch et } \\
\text { al., 2014) }\end{array}$} & $\begin{array}{l}\text { Lopadostomatace } \\
\text { ae }\end{array}$ & Xylariales \\
\hline $\begin{array}{l}\text { Lopadostoma } \\
\text { gastrinum }\end{array}$ & CBS $134632=$ LG4 & - & Ulmus minor & KC774584 & KC774584 & $\begin{array}{l}\text { (Jaklitsch et } \\
\text { al., 2014) }\end{array}$ & $\mathrm{T}$ & $\begin{array}{l}\text { Lopadostomatace } \\
\text { ae }\end{array}$ & Xylariales \\
\hline $\begin{array}{l}\text { Lopadostoma } \\
\text { turgidum }\end{array}$ & CBS $133207=\mathrm{LT} 2$ & Austria & Fagus sylvatica & NR_132036 & KC774618 & $\begin{array}{l}\text { (Jaklitsch et } \\
\text { al. 2014) }\end{array}$ & $\mathrm{T}$ & $\begin{array}{l}\text { Lopadostomatace } \\
\text { ae }\end{array}$ & Xylariales \\
\hline $\begin{array}{l}\text { Microdochium } \\
\text { phragmitis }\end{array}$ & CBS 285.71 & Poland & Phragmites australis & KP859013 & KP858949 & $\begin{array}{l}\text { (Hernandez- } \\
\text { Restrepo et } \\
\text { al. 2016) }\end{array}$ & $\mathrm{ET}$ & Microdochiaceae & Xylariales \\
\hline
\end{tabular}




\begin{tabular}{|c|c|c|c|c|c|c|c|c|c|}
\hline $\begin{array}{l}\text { Penicillium_chrysoge } \\
\text { num }\end{array}$ & $\begin{array}{l}\text { CBS 306.48=ATCC } \\
10106\end{array}$ & USA & - & JX997093 & JQ434684 & $\begin{array}{l}\text { (Houbraken } \\
\text { et al. 2012; } \\
\text { Ropars et al. } \\
\text { 2012) }\end{array}$ & $\mathrm{T}$ & Trichocomaceae & Eurotiales \\
\hline $\begin{array}{l}\text { Sarcopodium } \\
\text { circinatum }\end{array}$ & CBS 587.92 & - & - & KM231787 & HQ232168 & $\begin{array}{l}\text { (Summerbell } \\
\text { et al. 2011) }\end{array}$ & & Nectriaceae & Hypocreales \\
\hline $\begin{array}{l}\text { Sarcopodium } \\
\text { circinosetiferum }\end{array}$ & $\begin{array}{l}\text { CBS 100251/ NBRC } \\
33031\end{array}$ & Argentina & garden soil & KM231782 & HQ232170 & $\begin{array}{l}\text { (Summerbell } \\
\text { et al., 2011) }\end{array}$ & & Nectriaceae & Hypocreales \\
\hline $\begin{array}{l}\text { Sarcopodium } \\
\text { flavolanatum }\end{array}$ & CBS 112283 & Ecuador & Theobroma gileri & KM231785 & KM231649 & $\begin{array}{l}\text { (Lombard et } \\
\text { al. 2015) }\end{array}$ & & Nectriaceae & Hypocreales \\
\hline Selenodriella fertilis & CBS 772.83 & Australia & $\begin{array}{l}\text { Hakea baxteri } \\
\text { dead leaf }\end{array}$ & KP859055 & KP858992 & $\begin{array}{l}\text { (Hernandez- } \\
\text { Restrepo et } \\
\text { al. 2016) }\end{array}$ & $\mathrm{T}$ & Microdochiaceae & Xylariales \\
\hline $\begin{array}{l}\text { Vermiculariopsiella } \\
\text { immersa }\end{array}$ & MUCL39135 & Cuba & - & KJ476965 & KJ476961 & $\begin{array}{l}\text { (Becerra- } \\
\text { Hernández et } \\
\text { al., 2016) }\end{array}$ & & $\begin{array}{l}\text { Vermiculariopsie } \\
\text { llaceae }\end{array}$ & Microascales \\
\hline $\begin{array}{l}\text { Vermiculariopsiella } \\
\text { (Gyrothrix) } \\
\text { microsperma }\end{array}$ & NBRC 9374 & Japan & $\begin{array}{l}\text { dead leaf, } \\
\text { Castanopsis sp. }\end{array}$ & 937401 & 937401 & $\begin{array}{l}\text { (Becerra- } \\
\text { (Hernández- } \\
\text { Restrepo et } \\
\text { al. 2017; } \\
\text { Hernandez- } \\
\text { Restrepo et } \\
\text { al. 2016) }\end{array}$ & & $\begin{array}{l}\text { Vermiculariopsie } \\
\text { llaceae }\end{array}$ & Xylariales \\
\hline Xylaria hypoxylon & ATCC 42768 & USA & Wood & AY327477 & U47841 & $\begin{array}{l}\text { (Platas et al. } \\
\text { 2004) }\end{array}$ & & Xylariaceae & Xylariales \\
\hline Xylaria hypoxylon & CBS 122620 & Sweden & $\begin{array}{l}\text { old tree stump of } \\
\text { Sorbus aucuparia }\end{array}$ & AM993141 & KY610495 & $\begin{array}{l}\text { (Peršoh et al. } \\
\text { 2009; Wendt } \\
\text { et al. 2017) }\end{array}$ & ET & Xylariaceae & Xylariales \\
\hline
\end{tabular}

2

3 ATCC, American Type Culture Collection, Manassas, United States; BCC, BIOTEC Culture Collection, Thailand; CBS, The Westerdijk Fungal Biodiversity

4 Institute (formerly Centra albureau voor Schimmel cultures), Utrecht, The Netherlands; MFLUCC, Mae Fah Luang University Culture Collection, Chiang Rai,

5 Thailand; MUCL, BCCM Belgian Co-ordinated Collections of Microorganisms, Belgium (formerly The Mycothèque de l'Université catholique de Louvain);

6 NBRC, the NITE Biological Resource Center, Japan; UAMH, The UAMH Centre for Global Microfungal Biodiversity at University of Toronto. 